\title{
Impacts of Environmental Variations on Quality and Chemical Contents of Oriental Tobacco *
}

\author{
by \\ Dursun Kurt \\ Ondokuz Mayis University, Vocational High School of Bafra, Samsun, Turkey
}

\section{SUMMARY}

Basma tobaccos, in addition to Izmir and Samsun type tobaccos, are the most important high-quality oriental tobacco types grown in Turkey. This research was carried out to determine the effects of a variety of environmental conditions, in four locations on different altitudes on the yield as well as on nicotine, sugar and phenolic substances content. The plant material of the study included 21 Basma lines, which were selected according to their morphological differences and from genotypes separated by DNA fingerprint analysis, and four standard cultivars/lines (checks). The quality grade index of the genotypes was determined by the American grading method and chemical analyses were carried out using a high-performance liquid chromatography (HPLC) system. All the parameters investigated indicated that genotypes were significantly affected by the variation in environmental conditions. Organoleptic observations showed that the quality grade index of genotypes ranged from 24.17 to $100 \%$, and the ERB-7, ERB-13, ERB-15, ERB-19 and ERB-38 lines had the best quality. Nicotine contents of tobacco lines were between 0.31 and $3.15 \%$ dry matter (DM). Glucose, fructose and their sum (reducing sugar) contents of genotypes ranged from 1.16 to $8.88 \% \mathrm{DM}$, from 2.60 to $8.66 \% \mathrm{DM}$ and from 4.44 to $15.03 \%$ DM, respectively. The ERB-21 and ERB-30 lines are noteworthy tobacco types in terms of reducing sugar contents. The values of chlorogenic acid, one of the phenolic compounds, ranged from 40.67 to $1119.76 \mathrm{ppm}$, the values of rutin from 121.05 to 1021.53 ppm, and the sum of these two phenolic compounds was from $174.94 \mathrm{ppm}$ to $2019.41 \mathrm{ppm}$. The effect of variations in the environment on the quality of Oriental tobacco can be clearly explained by the variations in the parameters. [Contrib. Tob. Nicotine Res. 30 (2021) 50-62]

\section{KEY WORDS:}

Chemical quality; HPLC; grade index; alkaloids; sugars; phenolics

\section{ZUSAMMENFASSUNG}

$\mathrm{Zu}$ den wichtigsten hochwertigen Orienttabaksorten, die in der Türkei angebaut werden, zählen neben den Tabaken der Sorten Izmir und Samsun, die Basma-Tabake. Die vorliegende Untersuchung wurde durchgeführt, um den Einfluss einer Reihe von Umweltbedingungen an vier Standorten in verschiedenen Höhenlagen auf den Ertrag sowie auf den Gehalt an Nikotin, Zucker und phenolischen Substanzen zu bestimmen. Als Pflanzenmaterial wurden in die Studie vier Standardsorten / -linien (Kontrolle) sowie 21 Basma-Linien eingeschlossen. Diese wurden anhand ihrer morphologischen Unterschiede und aus Genotypen ausgewählt, welche durch Analyse des DNA-Fingerabdrucks ermittelt wurden. Der Qualitätsstufenindex der Genotypen wurde anhand des amerikanischen Graduierungsverfahrens bestimmt und es wurden chemische Analysen mithilfe der Hochleistungsflüssigkeitschromatografie (HPLC) durchgeführt. Alle untersuchten Parameter deuteten darauf hin, dass die Geno- 
typen signifikant durch sich ändernde Umweltbedingungen beeinflusst wurden. Organoleptische Beobachtungen ergaben, dass der Qualitätsstufenindex der Genotypen zwischen 24,17 und 100\% lag und dass die Linien ERB-7, ERB-13, ERB-15, ERB-19 und ERB-38 die höchste Qualität aufwiesen. Der Nikotingehalt der Tabaklinien lag zwischen 0,31 und 3,15\% der Trockensubstanz (TS). Der Gehalt an Glucose, Fructose und deren Summe (reduzierende Zucker) lag bei den Genotypen jeweils zwischen 1,16 und $8,88 \%$ TS, zwischen 2,60 und $8,66 \%$ TS und zwischen 4,44 und 15,03\% TS. Die Linien ERB-21 und ERB-30 waren in Hinblick auf ihren Gehalt an reduzierenden Zuckern bemerkenswert. Die Konzentrationen an Chlorogensäure, eine der Phenolverbindungen, variierten von 40,67 bis 1119,76 ppm, die Konzentrationen an Rutin lagen zwischen 121,05 und 1021,53 ppm und die Summe dieser zwei Phenolverbindungen variierte zwischen 174,94 und 2019,41 ppm. Anhand der Unterschiede bei den Parametern kann der Einfluss von Veränderungen in der Umwelt auf die Qualität von Orienttabak eindeutig erklärt werden. [Contrib. Tob. Nicotine Res. 30 (2021) 50-62]

\section{RESUME}

Les tabacs de Basma, aux côtés des variétés de type Samsun et Izmir, comptent parmi les plus importants tabacs d'Orient de qualité supérieure cultivés en Turquie. La présente étude fut menée dans le but de déterminer les effets d'un éventail de conditions environnementales, en quatre lieux situés à des altitudes différentes, sur le rendement ainsi que sur les teneurs en substances phénoliques, en sucre et en nicotine. Le matériel végétal retenu pour cette étude inclut d'une part, 21 lignées de Basma, sélectionnées selon leurs différences morphologiques et parmi des génotypes distingués par une analyse de l'empreinte ADN et d'autre part, quatre lignées/cultivars normalisés (contrôles). L'indice de classement de qualité des génotypes fut déterminé suivant la méthode de classement américaine et des analyses chimiques furent accomplies à l'aide d'une chromatographie en phase liquide à haute performance (CLHP). L'ensemble des paramètres étudiés indiquèrent que les génotypes étaient affectés de manière significative par la variation des conditions environnementales. Les observations organoleptiques mirent en évidence que l'indice de classement de qualité des génotypes se déployait sur une plage allant de 24,17 à $100 \%$ tandis que les lignées ERB-7, ERB-13, ERB-15, ERB-19 et ERB-38 affichèrent une qualité supérieure. Les teneurs en nicotine des lignées de tabac oscillèrent entre 0,31 et $3,15 \%$ de matière sèche (MS). Les teneurs en glucose, fructose et leur somme (sucre réducteur) des génotypes occupèrent des plages allant respectivement de 1,16 à $8,88 \%$ de $\mathrm{MS}$, de 2,60 à $8,66 \%$ de $\mathrm{MS}$ et de 4,44 à $15,03 \%$ de MS. Les lignées ERB-21 et ERB-30 se distinguèrent en termes de teneur en sucre réducteur. Les valeurs pour l'acide chlorogénique, un des composés phénoliques, oscillèrent entre 40,67 et 1 119,76 ppm, tandis que la plage pour les valeurs de rutine alla de 121,05 à 1021,53 ppm; la somme de ces deux composés phénoliques varia de 174,94 à 2019,41 ppm. Les effets des variations des conditions environnementales sur la qualité des tabacs d'Orient s'expliquent clairement par les variations des paramètres. [Contrib. Tob. Nicotine Res. 30 (2021) 50-62]

\section{INTRODUCTION}

In addition to their characteristic properties, Oriental tobaccos can show a wide variety of characteristics resulting from differences in environmental conditions and cultivation techniques. The quality concept for these tobaccos includes technological characteristics as well as aspects of consumption demand. Therefore, tobacco quality, which is a subjective phenomenon, varies depending on the type of product to be manufactured and the preference of the consumer. The quality of a leaf represents the characteristic of a tobacco type.

The leaf grows depending on the processes undertaken, from planting with the genotype $\times$ environment interaction, until the end product in the factory. The quality of a green leaf reaches its potential with subsequent curing, ageing and the manufacturing processes. Therefore, each tobacco type is considered a region-specific ecotype.

Temperature and precipitation are the main environmental variables affecting the performance of plant growth, productivity and chemical composition of tobacco plants (1). Nicotine and soluble carbohydrates contents have been reported to be positively related to the temperature, and negatively to the precipitation (2). These studies indicate that the quality has a positive relationship with drought resistance and flowering earliness, while having a negative relationship with leaf yield and disease resistance (3). Therefore, the aroma and basic quality characteristics of Oriental tobaccos depend largely on the soil characteristics and climate of the region where they are grown (4).

Long-time cultivation of autogamous plant populations in the same region is very important for the selection in breeding. It is significant in the cultivation of pure lines, most variations of which occur due to the effects of environmental conditions. Landraces consisting of different genotypes due to human selection, are a valuable selection material for breeders because of the improvement in their adaptability (5). Genetic variability in a population is important also for biodiversity. Adaptability of a tobacco population to changes in environmental conditions without variability is difficult and it thus becomes more prone to genetic fixation (6).

An increase in the starch content of the leaf also enhances the leaf thickness (7). Increasing the number of upper leaves over time, to protect the lower leaves in Oriental tobacco, is explained by this way of adaptation mechanism. The ability of Oriental tobacco of maintaining the physical and biological properties as well as yield potential in arid ecosystems can be attributed to the high efficiency in use of water and nitrogen of these tobacco types. Environmental influences also stimulate the plants to conserve their performances by developing biochemical and morphological mechanisms, which create quality attributes that distinguish Oriental tobaccos from others. In other words, the quality criteria of Oriental tobaccos, such as leaf size, color, tip angle, hygroscopicity and thickness, are the characteristics generated during the adaptation process against stressors (8). 
Alkaloids are known for their direct impact on tobacco quality and usability. Nicotine, the most abundant alkaloid in tobacco among more than 20 other alkaloids, is the essential component that leads to consumption of tobacco products worldwide (9). Other tobacco alkaloids with less pharmacologically active substance content and impact are nornicotine, anabasine and anatabine (10). Glucose and fructose are the most important soluble sugars and are called reducing sugars $(11,12)$. The leaves with higher reducing sugar content are preferred for tobacco products (13). Sugars are known to balance the smoke flavor primarily by abating the sensory effects of nicotine and other tobacco alkaloids (14). A typical American blend contains 3 to $15 \%$ Oriental tobacco, and the total sugar content of the blend is approximately $12 \%$ which is composed of $8 \%$ natural and $4 \%$ additional sweeteners (11). Polyphenols that determine the color, flavor and smell of tobacco (16) are the most important secondary metabolites due to their containing tannins, coumarin, flavonoids and their derivatives (15). Polyphenol content is important in tobacco processing, as well as in blending and quality control processes (9). Polyphenols are vital components $(18,19)$ due to their contribution to the sensory properties as well as to color, flavor, and smell of tobacco leaf and in addition to their antioxidant properties (17). Polyphenolic ingredients are sensitive to genotype and environment. Therefore, determining the polyphenol contents of a blend and grades of tobacco is very important (20). The impact of environmental and growing conditions on the polyphenol content of tobacco is higher than the genotype effect. The main polyphenols in tobacco are chlorogenic acid and rutin, their combustion products called catechols are known to be carcinogenic $(16,21,22)$. Therefore, the reliable characterization of chemical structures in the definition of leaf tobaccos is necessary for blenders in order to determine the potential toxicity risk $(23,24)$.

\section{MATERIAL AND METHODS}

\section{Material}

In 2015 Basma tobacco types in different growing regions of Turkey were screened, morphologically different plants were identified and seeds were collected. The DNA fingerprint analysis of the collected seeds indicated 27 different tobacco lines (Figure 1). Plant material of the study consisted of 21 Basma tobacco lines from the 27 identified lines and four standard tobacco lines (Xanthi 2A, Xanthi 81, Nail and Canik 190-5) (25). Selected plants were isolated using a paper bag to prevent outcrossing. Selfpollinated seeds were harvested after they reached maturity.

\section{Setting up the experiment}

Seedlings of the 25 genotypes were grown in a float tray system with a peat medium. Composite fertilizer containing $20 \%$ nitrogen $(\mathrm{N}), 10 \%$ phosphor $(\mathrm{P})$ and $20 \%$ potassium (K) plus micronutrients (iron $0.4 \%$, manganese $0.4 \%$ and zinc $0.4 \%$ ) was mixed with $500 \mathrm{~g} / \mathrm{m}^{3}$ water in float pond water to supply nutrients for the seedlings. The experimental fields, where the study material could be cultivated, were chosen in different altitudes. The research was carried out in Evciler $\left(40^{\circ} 36^{\prime} 43.48^{\prime \prime} \mathrm{N}, 36^{\circ} 36^{\prime} 5.25^{\prime \prime} \mathrm{E}, 581 \mathrm{~m}\right.$ altitude) and Karayaka $\left(40^{\circ} 44^{\prime} 16.45^{\prime \prime} \mathrm{N}, 36^{\circ} 33^{\prime} 58.31\right.$ "E, $302 \mathrm{~m}$ altitude), two villages of the Tokat-Erbaa, as well as in Bafra, a town in Samsun Province (41 ${ }^{\circ} 33^{\prime} 45.29^{\prime \prime} \mathrm{N}$, 35 52'18.35"E, $26 \mathrm{~m}$ altitude) and in Gümüşhacıköy, a town in Amasya Province $\left(40^{\circ} 53^{\prime} 1.03\right.$ "N, 35¹2'47.98E, $848 \mathrm{~m}$ altitude). Prior to planting the seedlings, $60 \mathrm{~kg} / \mathrm{ha} \mathrm{N}$, $40 \mathrm{~kg} / \mathrm{ha} \mathrm{P}_{2} \mathrm{O}_{5}$ and $60 \mathrm{~kg} / \mathrm{haK}_{2} \mathrm{O}$ were applied to the experimental fields (26). The field experiments were carried out in a randomized block design with three replications. The seedlings were planted with $45 \mathrm{~cm}$ inter-row and $12 \mathrm{~cm}$ intra-row spacing on 5-m long plots.

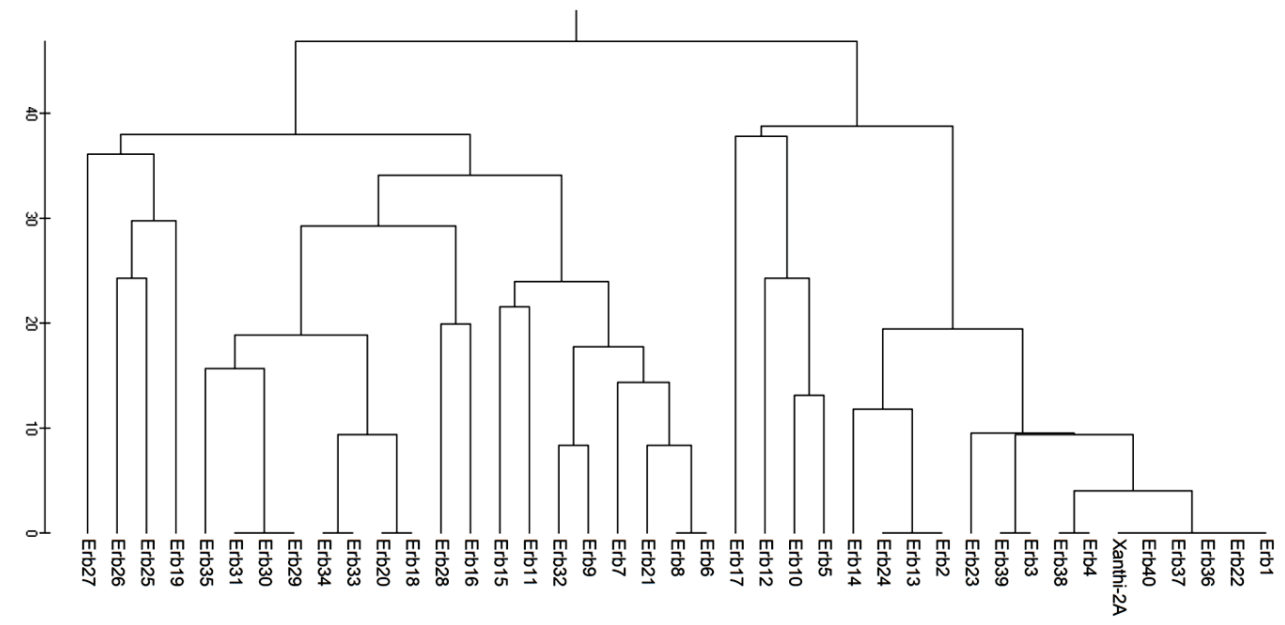

Figure 1. Dendrogram showing the genetic affinity of tobacco genotypes. 
Table 1. Soil analysis results of the locations.

\begin{tabular}{|c|c|c|c|c|c|c|c|c|}
\hline \multirow{2}{*}{ Properties } & \multicolumn{8}{|c|}{ Locations } \\
\hline & & Evciler & & Karayaka & Gü & üşhacıköy & & Bafra \\
\hline $\mathrm{P}_{2} \mathrm{O}_{5} \quad\left(\mathrm{~kg} \mathrm{ha}^{-1}\right)$ & 0.51 & low & 0.62 & moderate & 0.48 & low & 0.34 & low \\
\hline $\mathrm{K}_{2} \mathrm{O} \quad\left(\mathrm{kg} \mathrm{ha}^{-1}\right)$ & 16.97 & high & 17.53 & high & 15.68 & high & 13.72 & high \\
\hline Lime $\quad(\%)$ & 10.2 & $\begin{array}{l}\text { moderately } \\
\text { calcareous }\end{array}$ & 2.39 & calcareous & 5.17 & $\begin{array}{l}\text { moderately } \\
\text { calcareous }\end{array}$ & 12.73 & $\begin{array}{l}\text { moderately } \\
\text { calcareous }\end{array}$ \\
\hline Org. Mat. (\%) & 95 & very low & 143 & low & 2.36 & moderate & 1.76 & low \\
\hline $\mathrm{pH}$ & 7.99 & slightly alkaline & 7.81 & slightly alkaline & 7.98 & slightly alkaline & 7.61 & slightly alkaline \\
\hline $\begin{array}{l}\mathrm{EC} \quad\left(\mathrm{dS} \mathrm{m}^{-1}\right) \\
\text { Texture }\end{array}$ & 0.25 & $\begin{array}{l}\text { very low } \\
\text { clay loam }\end{array}$ & 0.13 & $\begin{array}{l}\text { very low } \\
\text { sandy loam }\end{array}$ & 1.12 & $\begin{array}{l}\text { very low } \\
\text { sandy loam }\end{array}$ & 0.72 & $\begin{array}{l}\text { very low } \\
\text { sandy loam }\end{array}$ \\
\hline
\end{tabular}

The seedlings were planted on May 21, 2017 in Evciler, May 19, 2017 in Karayaka, July 4, 2017 in Bafra and June 29, 2017 in Gümüşhacıköy. The harvest of mature leaves was completed in three different intervals, each of which was completed in one day.

The leaves were sun-cured, they were threaded onto needles and string and were hung under direct sunlight after being kept in shade for two days. The cured tobacco was baled and stored in a closed room. Data obtained in the different locations were not homogeneous; therefore, the locations were separately subjected to variance analysis using the SAS 9.0 software (59). Duncan's multiple comparison test was used to compare the parameters obtained in different locations and they were graphed with GraphPad Prism 8 program. Soils in the Evciler experimental field had a clay-loam texture and the other three locations had a sandy loam texture. Electrical conductivity levels indicated a very low soil salinity. All soils were slightly alkaline and the highest organic matter content was recorded in the experimental field of Gümüşhacıköy. Soils in Bafra and Karayaka fields had low and Evciler had very low organic matter content. Soils in the Evciler, Gümüşhacıköy and Bafra locations were moderately calcareous while soil in the Karayaka location was calcareous. Potassium contents of all experimental fields were high. Phosphorus contents of the experimental field in Karakaya were moderate while other three fields were low in phosphorus content (Table 1).

The temperature values during the seven-month period covering seedling, field and curing periods of the tobacco were similar to long-term averages, while the relative humidity values were higher than the long-term average values. The average relative humidity during this period was $69.86 \%$ in Erbaa, $64.43 \%$ in Gümüşhacıköy and $82.24 \%$ in Bafra. Total precipitation during the period of vegetative growth was $222.2 \mathrm{~mm}$ in Erbaa, $256.5 \mathrm{~mm}$ in Gümüşhacıköy and $222.1 \mathrm{~mm}$ in Bafra. Compared to the long-term average, there was less rain by $36.1 \mathrm{~mm}$ in Erbaa, by $47.1 \mathrm{~mm}$ in Gümüşhacıköy and by $152.2 \mathrm{~mm}$ in Bafra (Table 2).

\section{INVESTIGATED CHARACTERISTICS}

\section{Grade index}

The grade index is the quality score of organoleptic assessments carried out by a tobacco expert on the cured leaves rating properties as stalk position, leaf size, texture, odor, moisture condition, leaf shape, leaf tip angle, leaf venation, color and brightness status, leaf integrity, degradation and disease/pest status of leaves. The expert provides two-digit ratings for each tobacco unit, the first digit representing the stalk position and the second digit representing the quality group according to the aforementioned properties. The grade, which is the basis for the pricing of the product, is calculated by multiplying these degrees with a certain coefficient. The principle of grading is to determine the proportion of A grade tobacco in a certain amount of tobacco (American grading method). The grading is the key action that governs the direction of the product in all stages from processing, marketing and finally to the end product (27).

\section{Nicotine content}

For nicotine analysis (\% DM), a 200-mg ground moisturefree tobacco sample was weighed into a 50-mL Falcon tube and $1 \%$ aqueous acetic acid and acetonitrile $(85: 15, v / v)$ was added. The mixture was kept in an ultrasonic water bath for $30 \mathrm{~min}$. Samples removed from the water bath were centrifuged at $4000 \mathrm{rpm}$ for $10 \mathrm{~min}$. The remaining solution (supernatant) atop the precipitated sample was taken up by a syringe. The supernatant was passed through the filter (Nylon, $0.45 \mu \mathrm{m}$ ) and transferred into the vial marked with the sample number. Extractions were analysed using an Agilent technology 1260 series high-performance liquid chromatography (HPLC) system (Agilent Technologies, Boeblingen, Germany) equipped with an ACE C18 column $(250 \times 4.6 \mathrm{~mm}$ i.d. dimensions and $5 \mu \mathrm{m}$ particle size) with a flow rate of $1 \mathrm{~mL} / \mathrm{min}$, a column temperature of $35^{\circ} \mathrm{C}$ and a DAD (diode array detector) detector. The mobile phase consisted of $1 \%$ acetic acid in water (solvent A) and acetonitrile (solvent B). A wavelength of $324 \mathrm{~nm}$ was set for UV detection of alkaloids and nicotine was quantified using an authentic standard $(28,29)$.

\section{Reducing sugar (glucose and fructose) content}

For glucose and fructose analysis (\% DM), $1 \mathrm{~g}$ of ground moisture-free tobacco sample was weighed into a Falcon tube and $1 \%$ acetic acid and methanol $(75: 25, v / v)$ was added to the weighed sample. After adding the solvents, the mixture was stirred, then placed in an ultrasonic water bath and kept there for $30 \mathrm{~min}$. The samples were removed from the water bath and centrifuged at $4000 \mathrm{rpm}$ for $8 \mathrm{~min}$. 
Table 2. Monthly climate data during vegetative growth in the locations.

\begin{tabular}{|c|c|c|c|c|c|c|c|c|c|c|}
\hline \multirow{2}{*}{ Months } & & \multicolumn{3}{|c|}{ Erbaa } & \multicolumn{3}{|c|}{ Gümüşhacıköy } & \multicolumn{3}{|c|}{ Bafra } \\
\hline & & LTA. & 2017 & D. & LTA. & 2017 & D. & LTA. & 2017 & D. \\
\hline & ${ }^{\circ} \mathrm{C}$ & 14.2 & 12.4 & -1.8 & 11.0 & 10.0 & -1.0 & 11.2 & 9.9 & -1.3 \\
\hline \multirow[t]{3}{*}{ April } & $\mathrm{mm}$ & 55.4 & 45.2 & -10.2 & 56.9 & 43.6 & -13.3 & 57.7 & 63.0 & 5.3 \\
\hline & $\%$ & 58.6 & 65.2 & 6.6 & 58.7 & 62.9 & 4.2 & 79.0 & 85.8 & 6.8 \\
\hline & ${ }^{\circ} \mathrm{C}$ & 18.1 & 17.0 & -1.1 & 14.4 & 14.4 & 0 & 15.5 & 15.0 & -0.5 \\
\hline \multirow[t]{3}{*}{ May } & $\mathrm{mm}$ & 62.2 & 50.5 & -11.7 & 75.5 & 70.9 & -4.6 & 47.2 & 53.6 & 6.4 \\
\hline & $\%$ & 60.7 & 71.6 & 10.9 & 59.6 & 69.5 & 9.9 & 79.4 & 87.6 & 8.2 \\
\hline & ${ }^{\circ} \mathrm{C}$ & 21.6 & 21.4 & -0.2 & 18.2 & 18.4 & 0.2 & 20.1 & 20.3 & 0.2 \\
\hline \multirow[t]{3}{*}{ June } & $\mathrm{mm}$ & 48.4 & 94.5 & 46.1 & 74.9 & 87.3 & 12.4 & 34.6 & 45.9 & 11.3 \\
\hline & $\%$ & 58.1 & 73.6 & 15.5 & 58.9 & 79.2 & 20.3 & 74.9 & 84.7 & 9.8 \\
\hline & ${ }^{\circ} \mathrm{C}$ & 23.9 & 20.8 & -3.1 & 20.7 & 21.3 & 0.6 & 22.8 & 23.5 & 0.7 \\
\hline \multirow[t]{3}{*}{ July } & $\mathrm{mm}$ & 24.6 & 1.2 & -23.4 & 26.6 & 8.4 & -18.2 & 31.0 & 0 & -31 \\
\hline & $\%$ & 55.4 & 74.2 & 18.8 & 53.3 & 55.5 & 2.2 & 73.1 & 95.2 & 22.1 \\
\hline & ${ }^{\circ} \mathrm{C}$ & 23.8 & 25.9 & 2.1 & 21.1 & 22.3 & 1.2 & 22.9 & 24.3 & 1.4 \\
\hline \multirow[t]{3}{*}{ August } & $\mathrm{mm}$ & 9.9 & 1.0 & -8.9 & 11.3 & 9.2 & -2.1 & 47.3 & 24.8 & -22.5 \\
\hline & $\%$ & 55.6 & 65.8 & 10.2 & 50.9 & 67.7 & 16.8 & 74.5 & 75.2 & 0.7 \\
\hline & ${ }^{\circ} \mathrm{C}$ & 20.5 & 22.2 & 1.7 & 17.4 & 20.8 & 3.4 & 19.5 & 21.2 & 1.7 \\
\hline \multirow[t]{3}{*}{ September } & $\mathrm{mm}$ & 16.1 & 2.9 & -13.2 & 13.0 & 13.2 & 0.2 & 59.7 & 13.0 & -46.7 \\
\hline & $\%$ & 57.9 & 61.6 & 3.7 & 53.9 & 51.7 & -2.2 & 76.8 & 75.2 & -1.6 \\
\hline & ${ }^{\circ} \mathrm{C}$ & 15.4 & 13.9 & -1.5 & 12.3 & 12.2 & -0.1 & 15.4 & 15.4 & 0 \\
\hline \multirow[t]{2}{*}{ October } & $\mathrm{mm}$ & 41.7 & 26.9 & -14.8 & 45.4 & 23.9 & -21.5 & 96.8 & 21.8 & -75 \\
\hline & $\%$ & 63.2 & 77.0 & 13.8 & 61.4 & 64.5 & 3.1 & 78.7 & 72.0 & -6.7 \\
\hline \multicolumn{2}{|c|}{ Mean temperature $\left({ }^{\circ} \mathrm{C}\right)$} & 19.6 & 19.1 & -0.6 & 16.4 & 17.1 & 0.6 & 18.2 & 18.5 & 0.3 \\
\hline \multicolumn{2}{|c|}{ Total precipitation (mm) } & 258.3 & 222.2 & -36.1 & 303.6 & 256.5 & -47.1 & 374.3 & 222.1 & -152.2 \\
\hline \multicolumn{2}{|c|}{ Mean relative humidity $(\%)$} & 58.5 & 69.9 & 11.4 & 56.7 & 64.4 & 7.8 & 76.6 & 82.2 & 5.6 \\
\hline
\end{tabular}

LTA.: long term average (1963-2016); D: difference between 2017 and the years of 1963-2016;

${ }^{\circ} \mathrm{C}$ : temperature; mm: precipitation; \%: relative humidity

The remaining solution (supernatant) atop the precipitated sample was subsequently removed with a syringe. The supernatant was passed through a filter (Nylon, $0.45 \mu \mathrm{m}$ ) and transferred into the vial marked with the sample number. The content of glucose and fructose was analysed by HPLC using a RID (refractive index detector) with a Zorbax Carbohydrate column $(250 \times 4.6 \mathrm{~mm}$ i.d. dimensions and $5 \mu \mathrm{m}$ particle size) at $1.5 \mathrm{~mL}$ flow and $40{ }^{\circ} \mathrm{C}$ column temperature $(29,30)$. The mobile phase consisted of $1 \%$ acetic acid in water (solvent $\mathrm{A}$ ) and acetonitrile (solvent B) with $25 \% \mathrm{~A}$ and $75 \% \mathrm{~B}$.

\section{Phenolic (chlorogenic acid and rutin) content}

For chlorogenic acid and rutin analyses, $200 \mathrm{mg}$ ground moisture-free tobacco sample was weighed into a Falcon tube and 5\% acetic acid and methanol $(85: 15, v / v)$ was added into the tubes. After adding the solvents, the mixture was stirred, placed in an ultrasonic water bath and kept there for $30 \mathrm{~min}$. Samples were removed from the water bath and centrifuged at $4000 \mathrm{rpm}$ for $10 \mathrm{~min}$. The remaining solution (supernatant) atop the precipitated sample was removed with a syringe. The supernatant was passed through the filter (Nylon, $0.45 \mu \mathrm{m}$ ) and transferred into a vial marked with the sample number. The extract was analysed by HPLC with a poroshell 120 EC C18 column $(2.7 \mu \mathrm{m}, 150 \mathrm{~mm} \times 3.0 \mathrm{~mm}$ i.d. $)$ and a guard precolumn using a diode array detector (DAD) at a $0.3 \mathrm{~mL} / \mathrm{min}$ flow rate and a $35{ }^{\circ} \mathrm{C}$ column temperature. The mobile phase consisted of $1 \%$ acetic acid in water (solvent $\mathrm{A}$ ) and acetonitrile (solvent B) using an isocritical elution with $85 \% \mathrm{~A}$ and $15 \% \mathrm{~B}(20,29)$.

The peaks obtained from the sample chromatograms were identified by comparison with the peaks obtained from the standards and the area of each peak was calculated according to their standard calibrations $\left(\mathrm{r}^{2} ; 0.999\right.$ and 1.0). The concentrations of nicotine, glucose and fructose were given as percent $(\% \mathrm{DM})$ and those of chlorogenic acid and rutin as ppm. Extraction recovery rates, that indicate the reliability of the analysis, were $101 \%$ for nicotine, $106 \%$ for glucose, $102 \%$ for fructose, $83 \%$ for chlorogenic acid and $96 \%$ for rutin.

\section{RESULTS AND DISCUSSION}

\section{Quality grade index}

Pricing of tobacco marketed for its degustative properties is practically based on organoleptic estimates, which is a subjective assessment (31). The products with a $60 \%$ or higher grade A evaluation obtained the highest market price ( $\$ 4.86 / \mathrm{kg}$ ) during the study season in 2017 . Therefore, genotypes providing a $60 \%$ grade A rating have been categorized as high-quality. The A-grade rates of ERB-9, ERB-11, ERB-18, ERB-25 and ERB-27 lines were lower than $60 \%$. Despite the slight differences in the grade values of the remaining 20 genotypes, they were all very alike in quality and commercially on the same scale (Table 3, Figure 2). 


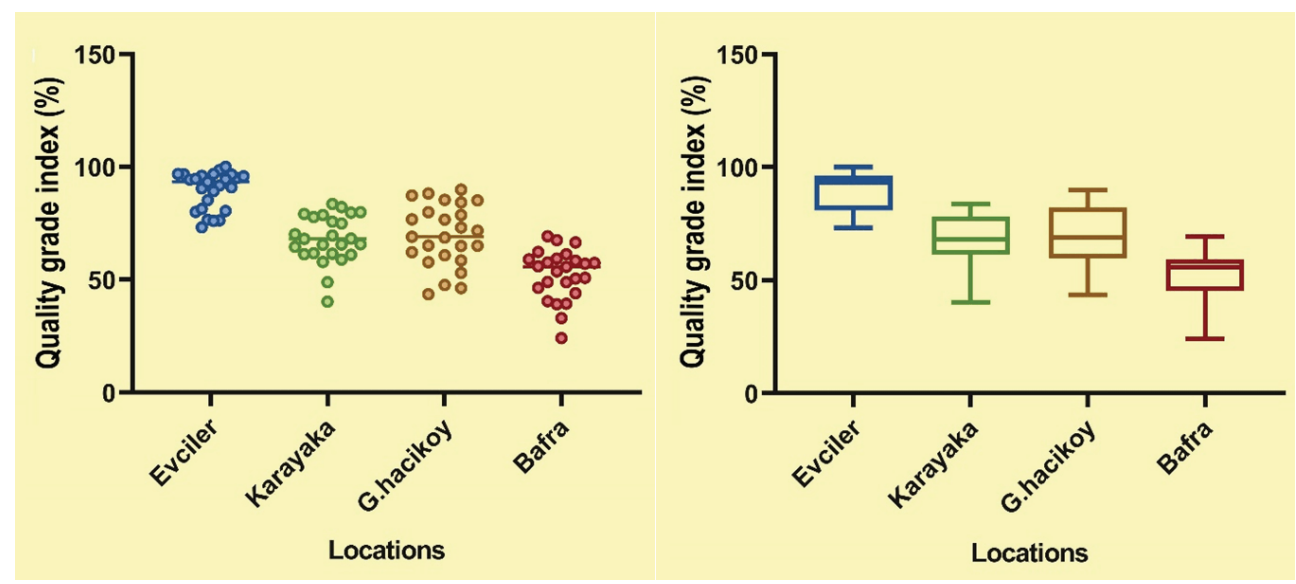

Figure 2. Variation in quality grade index (\% of A grades) values of 25 tobacco genotypes at four different locations.

The yield and grade values had an inverse relationship, indicating that factors such as soil and climate contributing to the yield increase, had a negative impact on quality $(3,32)$. The highest grade values and the lowest yield values were obtained in the Erbaa-Evciler location which corroborates the aforementioned inverse relationship between yield and quality grade. Environmental effects induce the plants to maintain their performance by developing biochemical and morphological mechanisms, which are responsible for the quality characteristics that distinguish Oriental tobacco from others $(4,8)$.

Rainwater contributes to the growth of more elastic and aromatic leaves in Gümüşhacıköy. This location benefits from more regular and continuous rainfall compared to the other locations and it is located in the highest altitude among all the locations (33).

The highest-quality tobaccos were grown in class II and III agricultural land, while the quality was lower in I class land $(34,35)$. Karayaka was the location where the best quality grade values were obtained due to the effects of the aforementioned factors. The Bafra location has class I agricultural land, therefore this location was included in the study. Water requirement of Oriental tobaccos for a maximum yield is around 400 to $600 \mathrm{~mm}$ depending on the length and the climate of the growing season. About $50 \%$ of the total water required in the field should be applied during the period of 30-40 days after planting to obtain healthy and resistant plants. The water demand rises to the highest level at 50-70 days after transplanting, and afterwards gradually decreases (36). Excessive irrigation increases the total leaf area, causes thinning of leaves, reduces leaf density and results in quality losses (33).

Color in tobacco is used as a guide in all stages, and defined as the maturity index in cases such as determining the harvest time of stalk positions. The most apparent characteristic of the change in parallel to the advancement in maturity is transformation of leaf colors to yellow, orange and brown following the breakdown of chlorophyll. The vitality, brightness and lightness or darkness of leaf color are important criteria that determine the quality of a particular tobacco type (37). The plants in turgor, due to the continuous water supply, grow more rapidly, and thus the leaves cannot exhibit the type characteristics. In this case, the product will be fine-textured, very low or flavor-free, easily burning, of low-nicotine content and light-colored, which is markedly different from the color of plants grown under regular circumstances (33). The leaf color of Samsun type tobaccos changes from yellow to dark red as cultivation locations are progressing from the lowland to the slopy lands. The curing period of tobacco plants grown in lowland is usually shorter and the color of leaves quickly turns into yellow due to the faster curing (38). Therefore, mostly B grade and partially Kapa group products have been produced in Bafra location.

\section{Nicotine content of leaves}

Each type of tobacco within a blend has defining effects on the physical and chemical quality composition, as well as reducing/increasing effects on the amount of nicotine. This fact also has a significant impact on the market demand for the Oriental tobacco types. The desired nicotine content in Basma type tobaccos in the market for the Turkish private sector is in the range of 2.00 to $2.75 \%$ DM (26). The nicotine content of tobacco grown in the Karayaka location meets this requirement (1.09-3.15\% DM; average 2.06\% $\mathrm{DM})$, while the nicotine content of 11 lines and 3 standards (Xanthi 2A, Nail, Xanthi 81) were 2.00\% DM or higher (Table 3, Figure 3). On the other hand, nicotine content of tobacco grown in Evciler, Gümüşhacıköy and Bafra locations remained below the expectations of the sector. Nicotine content of tobacco can be increased to meet the market demand of 2.00-2.75\% DM by agrigultural measures such as e.g., nitrogenous fertilization (26), by wider planting distances (39) and by topping (40). Since the assimilation of nitrogen takes place in the root system and the photosynthesis takes place in the leaves, organic compounds carrying carbon are synthesized only in the leaves, and nitrogenous compounds are synthesized in part in the root system. Therefore, various tobacco types rich in certain desired contents can be produced by modifying the external conditions (41). Topping on time and to a sufficient degree can cause the moving to a lower plant part of the photosynthesis products in the leaves, thus improving root growth and consequently facilitating assimilation of the nitrogenous compounds $(41,42)$. 
Table 3. Quality grade index and nicotine contents of $\mathbf{2 5}$ genotypes in four locations.

\begin{tabular}{|c|c|c|c|c|c|c|c|c|c|c|}
\hline \multirow{2}{*}{ Genotypes } & \multicolumn{5}{|c|}{ Quality grade index (\%) } & \multicolumn{5}{|c|}{ Nicotine (\% DM) } \\
\hline & Evciler & Karayaka & G.Hacıköy & Bafra & Mean & Evciler & Karayaka & G.Hacıköy & Bafra & Mean \\
\hline ERB-5 & $96.09 \mathrm{ad}$ & 74.96 ae & $65.05 \mathrm{fi}$ & 69.27 a & 76.34 & $0.71 \mathrm{fg}$ & $1.81 \mathrm{dh}$ & $1.02 \mathrm{bd}$ & $0.34 \mathrm{fg}$ & 0.97 \\
\hline ERB-6 & $90.97 \mathrm{ce}$ & $75.77 \mathrm{ad}$ & $71.75 \mathrm{dg}$ & 50.87 ae & 72.34 & 1.02 af & $1.28 \mathrm{gh}$ & $1.03 \mathrm{bd}$ & $0.32 \mathrm{fg}$ & 0.91 \\
\hline ERB-7 & $96.77 \mathrm{ac}$ & $79.93 \mathrm{ab}$ & $73.07 \mathrm{df}$ & $62.36 \mathrm{ac}$ & 78.03 & $1.16 \mathrm{ad}$ & $2.02 \mathrm{bg}$ & $0.59 \mathrm{hi}$ & 0.52 be & 1.07 \\
\hline ERB-9 & $80.06 \mathrm{gh}$ & $64.64 \mathrm{bg}$ & $43.63 \mathrm{k}$ & $39.37 \mathrm{df}$ & 56.92 & $0.87 \mathrm{cg}$ & $2.04 \mathrm{bg}$ & $0.78 \mathrm{di}$ & $0.31 \mathrm{~g}$ & 1.00 \\
\hline ERB-11 & $73.20 \mathrm{i}$ & $48.92 \mathrm{gh}$ & $69.00 \mathrm{eh}$ & $39.18 \mathrm{df}$ & 57.57 & $0.88 \mathrm{bg}$ & $1.49 \mathrm{fh}$ & $0.91 \mathrm{cg}$ & $0.46 \mathrm{bg}$ & 0.93 \\
\hline ERB-12 & $96.87 \mathrm{ac}$ & 68.19 af & $65.13 \mathrm{fi}$ & $56.00 \mathrm{ad}$ & 71.55 & $0.82 \mathrm{dg}$ & $2.69 \mathrm{ac}$ & $0.63 \mathrm{gi}$ & $0.61 \mathrm{ac}$ & 1.19 \\
\hline ERB-13 & $98.55 \mathrm{ab}$ & 69.60 af & $79.93 \mathrm{ad}$ & $66.52 \mathrm{ab}$ & 78.65 & $1.32 \mathrm{a}$ & $2.59 \mathrm{ad}$ & $0.86 \mathrm{ch}$ & $0.68 \mathrm{a}$ & 1.36 \\
\hline ERB-14 & $91.77 \mathrm{ce}$ & $61.81 \mathrm{cg}$ & $58.53 \mathrm{hj}$ & $57.65 \mathrm{ad}$ & 67.44 & $1.17 \mathrm{ac}$ & $2.58 \mathrm{ad}$ & $0.68 \mathrm{fi}$ & $0.48 \mathrm{bg}$ & 1.23 \\
\hline ERB-15 & $100.00 \mathrm{a}$ & $65.66 \mathrm{bf}$ & $88.26 a b$ & $57.10 \mathrm{ad}$ & 77.75 & $0.96 \mathrm{bf}$ & 2.30 be & $0.92 \mathrm{cg}$ & $0.57 \mathrm{ad}$ & 1.19 \\
\hline ERB-16 & 89.22 ef & $61.55 \mathrm{cg}$ & $76.78 \mathrm{ce}$ & $40.47 \mathrm{df}$ & 67.01 & $0.77 \mathrm{eg}$ & $1.09 \mathrm{~h}$ & $1.14 \mathrm{ac}$ & $0.41 \mathrm{dg}$ & 0.85 \\
\hline ERB-17 & $85.31 \mathrm{fg}$ & $61.30 \mathrm{cg}$ & $47.71 \mathrm{k}$ & 46.47 be & 60.20 & $1.16 \mathrm{ad}$ & $1.69 \mathrm{eh}$ & $0.96 \mathrm{cf}$ & $0.41 \mathrm{dg}$ & 1.06 \\
\hline ERB-18 & 76.55 hi & $61.04 \mathrm{dg}$ & 53.04 jk & 32.97 ef & 55.90 & $0.83 \mathrm{cg}$ & $2.01 \mathrm{cg}$ & $1.13 \mathrm{ac}$ & $0.47 \mathrm{bg}$ & 1.11 \\
\hline ERB-19 & $90.49 \mathrm{df}$ & $83.53 \mathrm{a}$ & $87.37 \mathrm{ac}$ & $57.41 \mathrm{ad}$ & 79.70 & $0.83 \mathrm{cg}$ & $2.07 \mathrm{bf}$ & $0.86 \mathrm{ch}$ & $0.49 \mathrm{bf}$ & 1.06 \\
\hline ERB-21 & $80.50 \mathrm{gh}$ & 65.54 bf & $85.38 \mathrm{ac}$ & $59.05 \mathrm{ad}$ & 72.62 & $1.05 \mathrm{ae}$ & $1.57 \mathrm{eh}$ & $0.93 \mathrm{cg}$ & $0.36 \mathrm{eg}$ & 0.98 \\
\hline ERB-23 & $95.12 \mathrm{ad}$ & 65.72 bf & $64.96 \mathrm{fi}$ & $67.54 \mathrm{a}$ & 73.34 & $1.14 \mathrm{ad}$ & $2.70 \mathrm{ac}$ & $0.94 \mathrm{cf}$ & $0.40 \mathrm{dg}$ & 1.29 \\
\hline ERB-25 & $76.35 \mathrm{hi}$ & $57.89 \mathrm{fg}$ & $60.80 \mathrm{hj}$ & $44.09 \mathrm{ce}$ & 59.78 & $0.99 \mathrm{fg}$ & $1.33 \mathrm{fh}$ & $0.92 \mathrm{cg}$ & $0.46 \mathrm{bg}$ & 0.92 \\
\hline ERB-26 & 94.35 ae & $78.73 a b$ & $57.80 \mathrm{ij}$ & $48.99 \mathrm{ae}$ & 69.96 & $0.95 \mathrm{bf}$ & $2.52 \mathrm{ad}$ & $0.74 \mathrm{di}$ & $0.47 \mathrm{bg}$ & 1.17 \\
\hline ERB-27 & $76.07 \mathrm{hi}$ & $40.33 \mathrm{~h}$ & $46.33 \mathrm{k}$ & $24.17 \mathrm{f}$ & 46.72 & $0.85 \mathrm{cg}$ & 1.53 eh & $0.73 \mathrm{di}$ & $0.46 \mathrm{bg}$ & 0.89 \\
\hline ERB-30 & 93.33 be & 70.14 af & 89.89 a & $48.87 \mathrm{ae}$ & 75.56 & 1.06 ae & $1.51 \mathrm{fh}$ & $1.35 a$ & $0.45 \mathrm{bg}$ & 1.09 \\
\hline ERB-35 & $81.44 \mathrm{gh}$ & $79.14 \mathrm{ab}$ & $85.21 \mathrm{ac}$ & $55.77 \mathrm{ad}$ & 75.39 & $0.70 \mathrm{fg}$ & $1.99 \mathrm{cg}$ & $0.53 \mathrm{i}$ & $0.60 \mathrm{ac}$ & 0.96 \\
\hline ERB-38 & $96.65 \mathrm{ac}$ & $77.77 \mathrm{ac}$ & $84.23 \mathrm{ac}$ & $53.72 \mathrm{ad}$ & 78.09 & 1.03 af & $2.66 \mathrm{ac}$ & $0.86 \mathrm{ch}$ & $0.44 \mathrm{cg}$ & 1.25 \\
\hline Xanthi 2A & $96.84 \mathrm{ac}$ & $82.19 \mathrm{a}$ & 78.73 be & $50.53 \mathrm{ae}$ & 77.07 & 0.99 af & $2.81 a b$ & 0.99 be & $0.57 \mathrm{ad}$ & 1.34 \\
\hline Nail & $94.62 \mathrm{ae}$ & 68.16 af & $62.19 \mathrm{gj}$ & $61.33 \mathrm{ac}$ & 71.58 & $1.08 \mathrm{ae}$ & $2.58 \mathrm{ad}$ & $0.78 \mathrm{di}$ & $0.40 \mathrm{dg}$ & 1.21 \\
\hline Canik 190-5 & 94.75 ae & $58.94 \mathrm{eg}$ & $68.70 \mathrm{eh}$ & $59.43 \mathrm{ad}$ & 70.45 & $0.54 \mathrm{~g}$ & $1.40 \mathrm{fh}$ & $1.25 \mathrm{ab}$ & $0.42 \mathrm{dg}$ & 0.90 \\
\hline Xanthi 81 & $95.81 \mathrm{ad}$ & $79.72 a b$ & $76.68 \mathrm{ce}$ & $58.46 \mathrm{ad}$ & 77.67 & $1.22 a b$ & $3.15 \mathrm{a}$ & 0.70 ei & $0.62 a b$ & 1.42 \\
\hline Mean & 89.67 & 68.05 & 69.61 & 52.30 & 69.91 & 0.96 & 2.06 & 0.89 & 0.47 & 1.09 \\
\hline M. checks & 95.50 & 72.26 & 71.57 & 57.44 & 74.19 & 0.96 & 2.48 & 0.93 & 0.50 & 1.22 \\
\hline M. lines & 88.56 & 67.25 & 69.23 & 51.32 & 69.09 & 0.97 & 1.97 & 0.88 & 0.46 & 1.07 \\
\hline $\operatorname{LSD}_{0.05}$ & 4.97 & 13.77 & 9.30 & 17.06 & & 0.28 & 0.66 & 0.25 & 0.14 & \\
\hline CV (\%) & 3.37 & 12.32 & 8.13 & 19.87 & & 17.97 & 19.65 & 17.14 & 18.80 & \\
\hline \multicolumn{6}{|c|}{ Mean square and significance } & & & & & $d f$ \\
\hline Genotype & $207.26^{\star *}$ & $336.07^{\star *}$ & $564.63^{* *}$ & $364.88^{* *}$ & & $0.10^{* *}$ & $0.98^{* *}$ & $0.12^{* *}$ & $0.03^{* *}$ & 24 \\
\hline Error & 9.15 & 70.31 & 32.09 & 107.99 & & 0.03 & 0.16 & 0.02 & 0.01 & 48 \\
\hline
\end{tabular}

* Values followed by different letters in each column are significantly different $\left({ }^{*} p<0.05\right)$ according to Duncan's test; LSD: least significant difference; CV: coefficent of variation; $d f$ : degree of freedom;

${ }^{* *} p<0.01$; Quality grade index: \% of A grades; M. checks: mean of checks; M. lines: mean of lines.

Nicotine content, which is synthesized at the root tips, is closely related to root growth (41). Despite the expectation of high nicotine content in tobacco from the Evciler location (42) due to drier conditions compared to other locations, root and therefore plant growth were weak which hampered the increase in nicotine content.

Oriental tobaccos have a different flavor, lower nicotine levels compared to commercial flue-cured Virginia and aircured Burley tobaccos and compared to Burley and bright tobaccos they also have lower tobacco specific nitrosamine (TSNA) levels. Therefore they are generally used in American blend type cigarettes by blending them with Virginia and Burley tobaccos (43). Precipitation and high humidity, especially during the harvest period, can delay maturation and leach down the resin and nicotine substances on the surface of the leaves. (44). Bafra is the location with the highest humidity.

If tobacco is cultivated in lighter soils, where the roots are well aerated and can take up the available water easily (under both limited nitrogen fertilization or under fertilized conditions), then tobacco with low levels of nitrogenous compounds is produced (41). The lower nicotine content of tobaccos grown in lowlands similar to the Bafra location has been attributed to a weaker root system as well as the lower fertility and less available nitrogen in lighter soils (8). CAMAS (45) studying regional tobaccos and their hybrids in Bafra stated that the lowest nicotine value of genotypes in the $\mathrm{F} 1$ generation was $0.47 \% \mathrm{DM}$ (mean $1.04 \% \mathrm{DM}$ ) in Basma 192-23 varieties. The decrease in nicotine content was reported for the hybrids related to the Basma variety, and the results were considered promising to obtain tobacco with a low nicotine content. CAMAs et al. (46) and ESENDAL et al. (47-49) reported that nicotine content in tobacco grown in the Bafra region ranged from 0.3 to $2.1 \%$ DM. The nicotine contents obtained in this study were similar to those reported in these studies carried out in Bafra. 

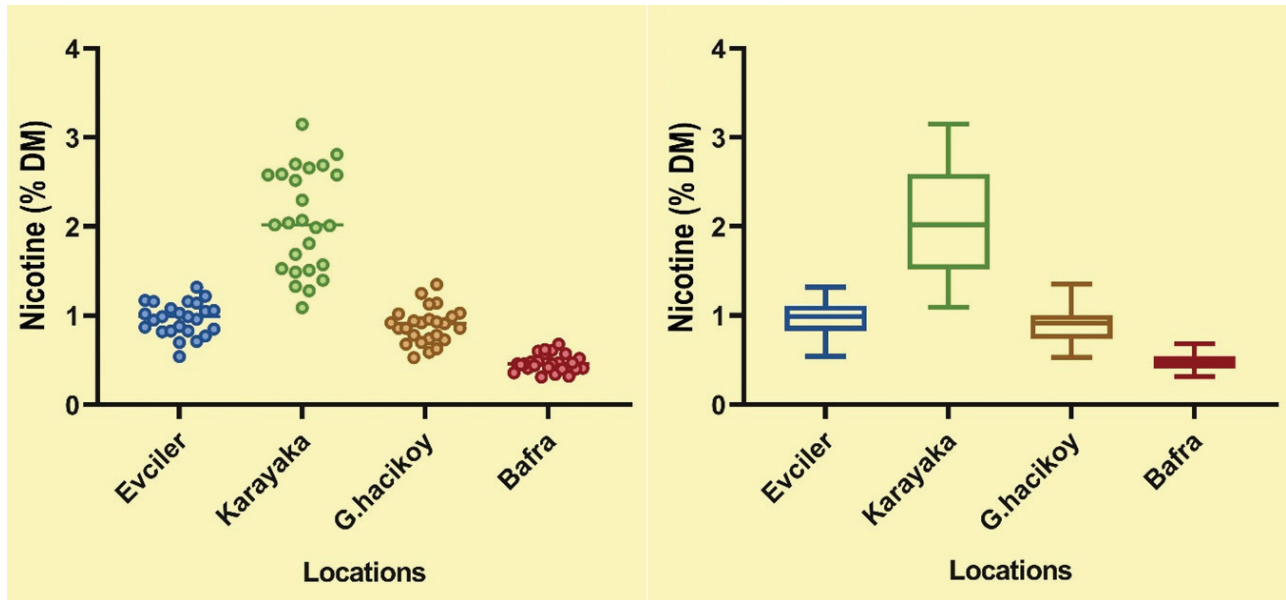

Figure 3. Variation in nicotine content of 25 tobacco genotypes at four different locations.

\section{Sugars}

Sugars, one of the most important components of the chemical structure of leaf tobacco, are primary metabolites (24) that contribute to the growth and development of tobacco plants. The reducing sugar composition is directly related to the taste and flavor of tobacco $(30,50,51)$. The sugar content in different tobacco types is quite variable and depends primarily on the curing process (14) where longer curing periods cause a decrease in the sugar content $(41,42,44)$.

Tobacco types are generally classified based on their curing methods. Reducing sugar in Oriental (sun-cured) and Virginia (flue-cured) tobaccos are relatively high (10-25\% DM) compared to the reducing sugar content $(<2 \% \mathrm{DM})$ in Burley and Maryland (air-cured) tobaccos (53). Fructose content in this study was between 2.60 and $8.66 \%$ DM (Table 4). The fructose content of American blends, of which Virginia, Burley and Oriental tobacco are the main raw materials, is between 3.98 and $5.76 \%$ DM (52). Reducing sugar composition, together with phenolic compounds, resins and essential oils, determines the taste and flavor of tobacco $(30,50,51)$. The reducing sugar content of an American blend is between 4.92 and 8.28\% DM (52).
Late planting in the Gümüşhacıköy location caused a delay in the harvest and curing period and as a consequence the curing of the $2^{\text {nd }}$ hand harvest was postponed to September. Decreasing temperatures in September made for a longer curing period. The temperatures in Erbaa after the $2^{\text {nd }}$ hand harvest went up to $25.9^{\circ} \mathrm{C}$, but the temperatures in August/ September, when the $2^{\text {nd }}$ hand is cured in Gümüşhacıköy, were only at 22.3 and $20.8{ }^{\circ} \mathrm{C}$. Similar conditions were found in the Bafra location where the $2^{\text {nd }}$ hand harvest was harvested on September 4. There the temperature in the curing period was $21.2^{\circ} \mathrm{C}$ (Table 2$)$. The excessive relative humidity in addition to the lower ambient temperatures during the curing period caused a decrease of the sugar content. This was due to the prolonged curing period $(41,42)$. Bafra is the location with the highest relative humidity among the locations (Table 2). The lowest reducing sugar content of Bafra, compared to the other locations, can be attributed to those low temperatures and high relative humidity throughout the curing period. The reducing sugar content in high demand by leaf tobacco companies for the Basma type tobacco is between 8 and $13 \%$ DM (26), and indeed the average reducing sugar content in the study ranged from 6.60 to $10.57 \%$ DM (mean 8.58\% DM) (Table 4, Figure 4).

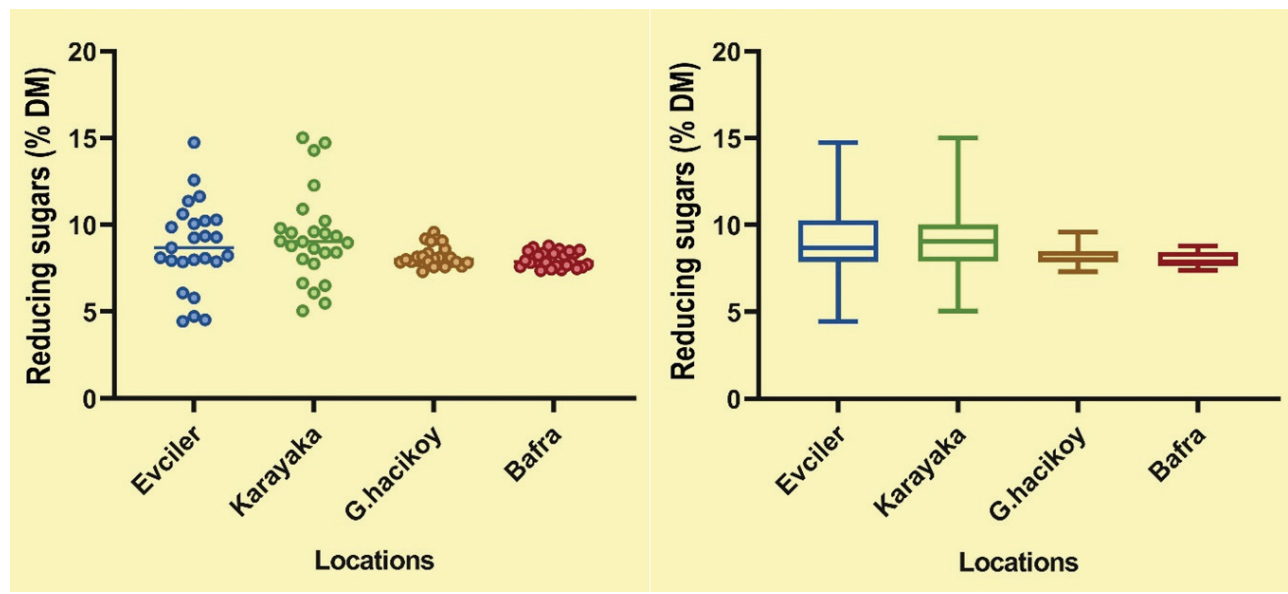

Figure 4. Variation in reducing sugars (glucose + fructose) content of 25 tobacco genotypes at four different locations. 
Table 4. Glucose, fructose and reducing sugar content of 25 genotypes in four locations.

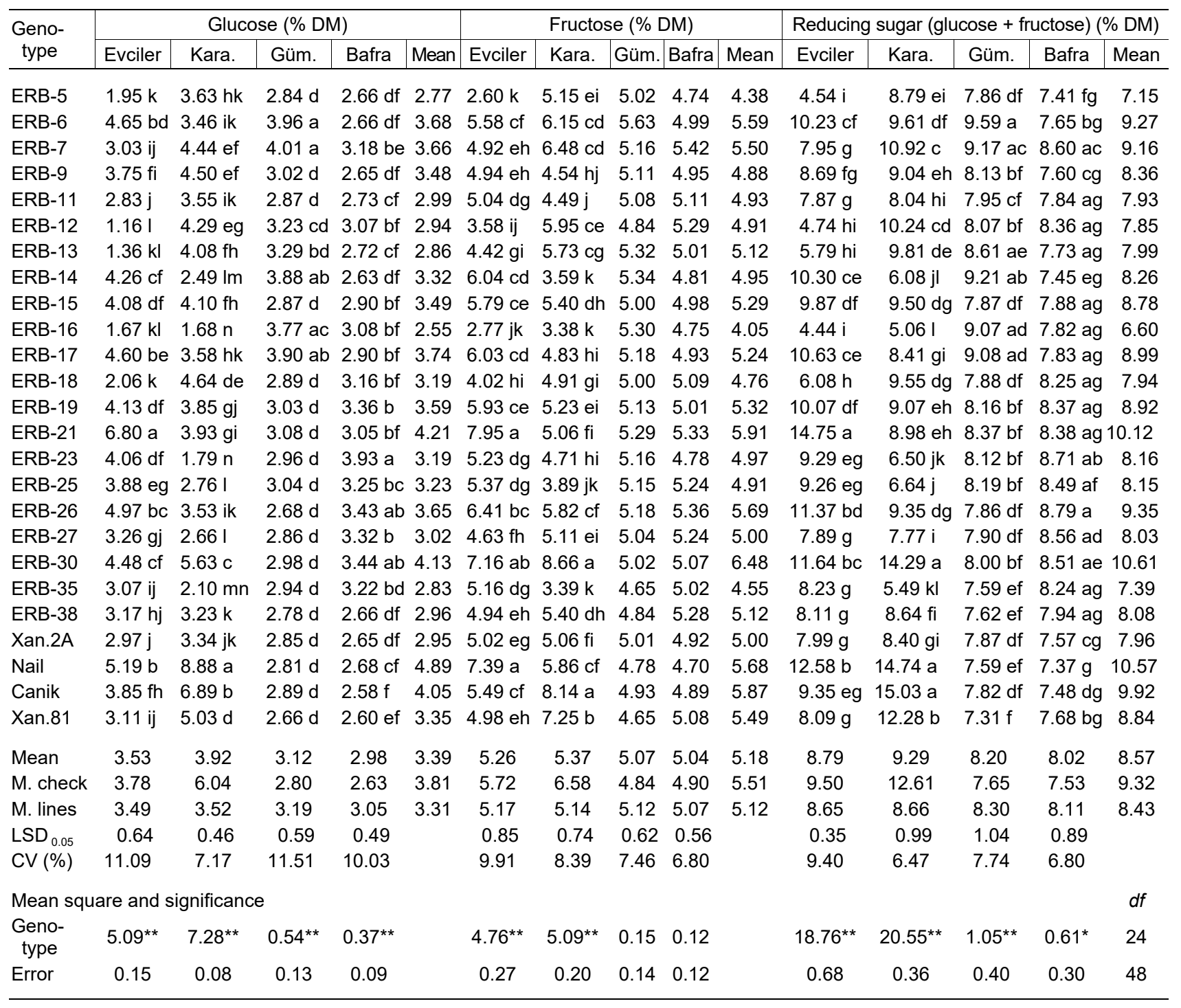

*Values followed by different letters in each column are significantly different $\left({ }^{*} p<0.05\right)$ according to Duncan's test;

LSD: least significant difference; CV: coefficent of variation; df: degree of freedom;

** $p<0.01$; M. check: mean of checks; M. lines: mean of lines.

\section{Phenolics}

Secondary metabolites, in addition to nicotine and reducing sugars that directly affect the color, taste and flavor of tobacco and thus determine the characteristics of the smoking product, should be taken into consideration during the planning and production processes. The most important of these secondary metabolites are polyphenols and among them the most abundant in tobacco are chlorogenic acid and rutin (17). The chlorogenic acid values in this study were between 156.70 and 426.73 ppm (Table 5).

The chlorogenic acid contents reported in various studies for Oriental tobacco were between 0.16 and $0.25 \% \mathrm{DM}$ (54), $1.56 \mathrm{mg} \mathrm{g}^{-1}$ (15), $30.2 \mathrm{mg} \mathrm{g}^{-1}$ (55), $7.9 \mathrm{mg} \mathrm{g}^{-1}$ (56) and between 4.5 and $12.3 \mathrm{mg} \mathrm{g}^{-1}$ (57). Rutin contents in Oriental tobacco were reported as $1.28-1.52 \%$ DM (44), 0.49$0.98 \%$ DM (58), 0.55-0.66\% DM (54), $4.240 \mathrm{mg} \mathrm{g}^{-1}$ (15), $2.8 \mathrm{mg} \mathrm{g}^{-1}$ (55), $6.2 \mathrm{mg} \mathrm{g}^{-1}$ (56), and 5.6-9.3 $\mathrm{mg} \mathrm{g}^{-1}$ (57). The mean rutin content of lines in all locations was be- tween 399.94 and $582.60 \mathrm{ppm}$, while the variation of each line at each location was between 121.05 and $1021.53 \mathrm{ppm}$ (Table 5).

The content of chlorogenic acid + rutin, which constituted approximately $85 \%$ of the total polyphenols (44), was similar or lower compared to those reported in previous studies $(15,44,54-58)$. The mean total contents of chlorogenic acid + rutin were 1018.95 ppm in Evciler, 1246.38 ppm in Karayaka, 478.42 ppm in Gümüşhacıköy and 328.96 ppm in Bafra (Table 5, Figure 5).

Chlorogenic acid + rutin content in Oriental tobacco was reported as $0.84-2.41 \% \mathrm{DM}$ (58), 0.71-0.91\% DM (54), $33.00 \mathrm{mg} \mathrm{g}^{-1}$ (55), $14.10 \mathrm{mg} \mathrm{g}^{-1}(56)$ and $10.10-21.60 \mathrm{mg} \mathrm{g}^{-1}$ (57). XIE et al. (15) reported chlorogenic acid + rutin content as 2.3\% DM for flue-cured, 0.054\% DM for Burley and $1.08 \%$ DM for Oriental tobaccos. Phenolic compounds directly contribute to the formation of leaf color, and oxidation of phenolic compounds causes mutations towards dark brown tones. The amount of chlorogenic acid increases 
Table 5. Chlorogenic acid, rutin and the sum of chlorogenic acid + rutin amounts of $\mathbf{2 5}$ genotypes in four locations.

\begin{tabular}{|c|c|c|c|c|c|c|c|c|c|c|c|c|c|c|c|}
\hline \multirow{2}{*}{ Genotype } & \multicolumn{5}{|c|}{ Chlorogenic acid (ppm) } & \multicolumn{5}{|c|}{ Rutin (ppm) } & \multicolumn{5}{|c|}{ Chlorogenic acid + rutin (ppm) } \\
\hline & Evciler & Kara. & Güm. & Bafra & Mean & Evciler & Kara. & Güm. & Bafra & Mean & Evciler & Kara. & Güm. & Bafra & Mean \\
\hline RB-5 & $248 \mathrm{ij}$ & $534 \mathrm{fg}$ & $83 \mathrm{kl}$ & $41 \mathrm{j}$ & 226.4 & $638 \mathrm{fk}$ & 615 ef & $304 \mathrm{ce}$ & 144 hj & 425.3 & $886 \mathrm{ij}$ & 1149 از & $387 \mathrm{gi}$ & $185 \mathrm{kl}$ & 651.7 \\
\hline & $490 \mathrm{a}$ & $773 d$ & $164 \mathrm{c}$ & $74 \mathrm{gi}$ & 375.3 & $677 \mathrm{dh}$ & $857 \mathrm{ab}$ & $389 \mathrm{bc}$ & 189 ej & 528.1 & $1167 \mathrm{bd}$ & $1630 \mathrm{bc}$ & $553 \mathrm{bc}$ & $263 \mathrm{gk}$ & 903.4 \\
\hline RB-7 & 483 a & $528 \mathrm{fh}$ & 751 & $136 \mathrm{~cd}$ & 305.6 & 999 a & $729 \mathrm{~cd}$ & $309 \mathrm{ce}$ & $293 \mathrm{ac}$ & 582.6 & 1482 a & 1256 hj & $385 \mathrm{gi}$ & $429 \mathrm{bc}$ & 888.3 \\
\hline ERB-9 & $414 \mathrm{bc}$ & $385 \mathrm{j}$ & $95 \mathrm{j}$ & 63 hj & 239.3 & 661 ej & $464 \mathrm{~h}$ & $358 \mathrm{bd}$ & $143 \mathrm{hj}$ & 406.6 & 1076 bg & 8480 & $453 \mathrm{dh}$ & 206 il & 645.9 \\
\hline RB-11 & $394 \mathrm{bd}$ & $449 \mathrm{i}$ & $109 \mathrm{i}$ & $116 \mathrm{df}$ & 267.1 & $1021 \mathrm{a}$ & 613 ef & 334 be & $303 a b$ & 567.9 & $1415 \mathrm{a}$ & $1062 \ln$ & $443 \mathrm{eh}$ & 419 bd & 835.0 \\
\hline & $343 \mathrm{dg}$ & $727 \mathrm{~d}$ & 751 & $119 \mathrm{df}$ & 315.9 & $544 \mathrm{kl}$ & $669 \mathrm{df}$ & 249 e & $217 \mathrm{dg}$ & 419.9 & 886 ij & $1396 \mathrm{eg}$ & $324 \mathrm{i}$ & $337 \mathrm{eg}$ & 735.9 \\
\hline & $407 \mathrm{bc}$ & $531 \mathrm{fh}$ & $118 \mathrm{gh}$ & $235 a$ & 322.8 & $694 \mathrm{dh}$ & $673 \mathrm{df}$ & 375 bd & $305 a b$ & 511.8 & 1101 be & 1203 ik & $494 \mathrm{bf}$ & $539 a$ & 834.6 \\
\hline & $300 \mathrm{gh}$ & $474 \mathrm{gi}$ & $112 \mathrm{hi}$ & 99 eg & 246.5 & $732 \mathrm{cf}$ & $646 \mathrm{df}$ & $297 \mathrm{de}$ & $230 \mathrm{cf}$ & 476.5 & 1032 eh & 1120 km & $409 \mathrm{fh}$ & 329 eg & 723.0 \\
\hline ERB-15 & $322 \mathrm{eg}$ & $532 \mathrm{fg}$ & $125 \mathrm{fg}$ & $84 \mathrm{gi}$ & 265.9 & $642 \mathrm{fk}$ & $669 \mathrm{df}$ & $388 \mathrm{bc}$ & 253 be & 488.1 & $964 \mathrm{fi}$ & 1201 ik & 513 be & $338 \mathrm{eg}$ & 754.1 \\
\hline ERB-16 & $309 \mathrm{gh}$ & $364 \mathrm{j}$ & $146 \mathrm{~d}$ & $140 \mathrm{~cd}$ & 239.7 & $647 \mathrm{fj}$ & $455 \mathrm{~h}$ & $421 a b$ & 253 be & 444.2 & $956 \mathrm{gi}$ & 819 o & $567 \mathrm{~b}$ & $393 \mathrm{ce}$ & 683.9 \\
\hline & $374 \mathrm{ce}$ & $492 \mathrm{gi}$ & $185 \mathrm{~b}$ & & 278.1 & $724 \mathrm{cg}$ & $597 \mathrm{fg}$ & & $166 \mathrm{fj}$ & 490.6 & 1098 bf & $\mathrm{km}$ & $9 a$ & $7 \mathrm{hk}$ & 768.6 \\
\hline & $367 \mathrm{cf}$ & $734 \mathrm{~d}$ & $153 d$ & $129 \mathrm{ce}$ & 345.8 & 594 hk & $596 \mathrm{fg}$ & $5 \mathrm{bd}$ & $156 \mathrm{gj}$ & 427.7 & $962 \mathrm{gi}$ & 0 fh & & $5 \mathrm{gi}$ & 773.6 \\
\hline 19 & $261 \mathrm{hi}$ & $932 \mathrm{~b}$ & $122 \mathrm{fg}$ & $94 \mathrm{fh}$ & 352.5 & $459 \mathrm{Im}$ & $649 \mathrm{df}$ & $331 \mathrm{ce}$ & $212 \mathrm{dh}$ & 412.9 & $719 \mathrm{k}$ & $1581 \mathrm{~cd}$ & & $307 \mathrm{fh}$ & 765.4 \\
\hline RB-21 & $444 a b$ & 877 bc & $204 a$ & $74 \mathrm{gi}$ & 399.8 & 758 be & $834 a b$ & $479 a$ & $171 \mathrm{fj}$ & 560.7 & $1203 b$ & $1710 \mathrm{~b}$ & $683 a$ & $245 \mathrm{hk}$ & 960.5 \\
\hline ER-23 & $310 \mathrm{gh}$ & $721 \mathrm{~d}$ & $190 \mathrm{~b}$ & $55 \mathrm{ij}$ & 319.3 & $754 \mathrm{ce}$ & $697 \mathrm{ce}$ & 487 a & 141 ij & 519.7 & $1064 \mathrm{cg}$ & 1417 ef & $677 a$ & 196 اj & 838.9 \\
\hline-25 & $408 \mathrm{bc}$ & $616.4 \mathrm{e}$ & 129 ef & $158 \mathrm{bc}$ & 327.9 & $573 \mathrm{ik}$ & $514 \mathrm{gh}$ & $301 \mathrm{ce}$ & $295 \mathrm{ac}$ & 420.8 & 981 ei & $\mathrm{km}$ & & $4 \mathrm{bc}$ & 748.8 \\
\hline-26 & $366 \mathrm{cf}$ & $1120 a$ & $90 \mathrm{jk}$ & $130 \mathrm{ce}$ & 426.7 & $674 \mathrm{di}$ & $899 a$ & 337 be & $213 \mathrm{dh}$ & 530.8 & $1040 \mathrm{dg}$ & $2019 a$ & 427 & $3 \mathrm{dg}$ & 957.6 \\
\hline & $239 \mathrm{ik}$ & $857 \mathrm{c}$ & $83 \mathrm{kl}$ & $175 b$ & 338.7 & 797 bc & $638 \mathrm{df}$ & 333 be & $308 a b$ & 519.2 & $1036 \mathrm{dg}$ & $5 \mathrm{de}$ & 41 & $4 a b$ & 857.9 \\
\hline ERB-30 & $326 \mathrm{eg}$ & $338 \mathrm{j}$ & $168 \mathrm{c}$ & $130 \mathrm{ce}$ & 240.6 & $851 \mathrm{~b}$ & $780 \mathrm{bc}$ & $370 \mathrm{bd}$ & 325 a & 581.8 & 1177 bc & 1118 km & $538 \mathrm{bd}$ & $455 \mathrm{bc}$ & 822.4 \\
\hline ERB-35 & $222 \mathrm{ik}$ & $180 \mathrm{k}$ & $83 \mathrm{kl}$ & $142 \mathrm{~cd}$ & 156.7 & $565 \mathrm{jk}$ & $482 \mathrm{~h}$ & $293 \mathrm{de}$ & 259 ae & 399.9 & 787 jk & $662 p$ & $376 \mathrm{hi}$ & $401 \mathrm{ce}$ & 556.6 \\
\hline 3-38 & $331 \mathrm{eg}$ & $332 \mathrm{j}$ & $171 \mathrm{c}$ & $80 \mathrm{gi}$ & 228.7 & $623 \mathrm{gk}$ & $643 \mathrm{df}$ & $287 \mathrm{de}$ & $194 \mathrm{di}$ & 436.9 & $954 \mathrm{gi}$ & $975 n$ & $459 \mathrm{dh}$ & $274 \mathrm{gj}$ & 665.6 \\
\hline Kan.2A & $193 k$ & $467 \mathrm{hi}$ & $137 \mathrm{e}$ & $79 \mathrm{gi}$ & 219.2 & $706 \mathrm{cg}$ & $818 a b$ & $291 \mathrm{de}$ & $199 \mathrm{di}$ & 503.9 & 899 hj & $1286 \mathrm{gi}$ & $428 \mathrm{eh}$ & $279 \mathrm{gi}$ & 723.2 \\
\hline Nail & $313 \mathrm{fh}$ & $752 \mathrm{~d}$ & $104 \mathrm{i}$ & $54 \mathrm{ij}$ & 305.7 & $641 \mathrm{fk}$ & 629 ef & $293 \mathrm{de}$ & $121 \mathrm{j}$ & 420.9 & $954 \mathrm{gi}$ & $1380 \mathrm{fg}$ & $397 \mathrm{gi}$ & 175 I & 726.6 \\
\hline Canik & 199 jk & 582 ef & $149 \mathrm{~d}$ & $85 \mathrm{gi}$ & 253.9 & $417 \mathrm{~m}$ & $662 \mathrm{df}$ & $343 \mathrm{bd}$ & $193 \mathrm{di}$ & 403.8 & $616 I$ & $1244 \mathrm{hj}$ & 492 bf & $278 \mathrm{gi}$ & 657.8 \\
\hline Xan.81 & $249 \mathrm{ij}$ & $386 \mathrm{j}$ & $119 \mathrm{gh}$ & $118 \mathrm{df}$ & 218.2 & $765 \mathrm{bd}$ & $644 \mathrm{df}$ & $355 \mathrm{bd}$ & $262 \mathrm{ad}$ & 506.7 & 1014 ei & $1030 \mathrm{mn}$ & $475 \mathrm{cg}$ & $381 \mathrm{cf}$ & 724.9 \\
\hline & 332.6 & 587.4 & & & 288.7 & & & & 221.9 & 479.5 & & & & 8.9 & \\
\hline neck & 238.6 & 546.9 & 127.6 & & 249.3 & 632.1 & 688.5 & 320.7 & 193.9 & 458.8 & 870.7 & 123 & 448.2 & 278.1 & 708.1 \\
\hline M. lines & 350.5 & 595.2 & 127.7 & 111.3 & 296.2 & 696.7 & 653.3 & 356.4 & 227.3 & 483.4 & 1047.2 & 1248.5 & 484.2 & 338.6 & 779.6 \\
\hline LSD $_{0.05}$ & 48.35 & 57.06 & 7.79 & 27.67 & & 87.50 & 83.20 & 75.16 & 59.36 & & 115.20 & 102.40 & 76.57 & 70.57 & \\
\hline CV (\%) & 8.85 & 5.91 & 3.71 & 15.75 & & 7.76 & 7.69 & 13.05 & 16.29 & & 6.88 & 5.01 & 9.75 & 13.07 & \\
\hline \multicolumn{6}{|c|}{ Mean square and significance } & & & & & & & & & & \\
\hline $\begin{array}{l}\text { Geno- } \\
\text { type }\end{array}$ & ** & ** & ** & ** & & ** & ** & ** & ** & & ** & ** & ** & ** & 24 \\
\hline Error & 867 & 1208 & 22.54 & 284 & & 2840.52 & 2567 & 2096 & 1307 & & 4921 & 3891 & 2175 & 1847 & 48 \\
\hline
\end{tabular}

* Values followed by different letters in each column are significantly different $\left({ }^{*} p<0.05\right)$ according to Duncan's test;

LSD: Least significant difference; CV: Coefficent of variation; $d f$ : degree of freedom; ${ }^{\star \star} p<0.01$; M. check: Mean of checks;

M. lines: Mean of lines.

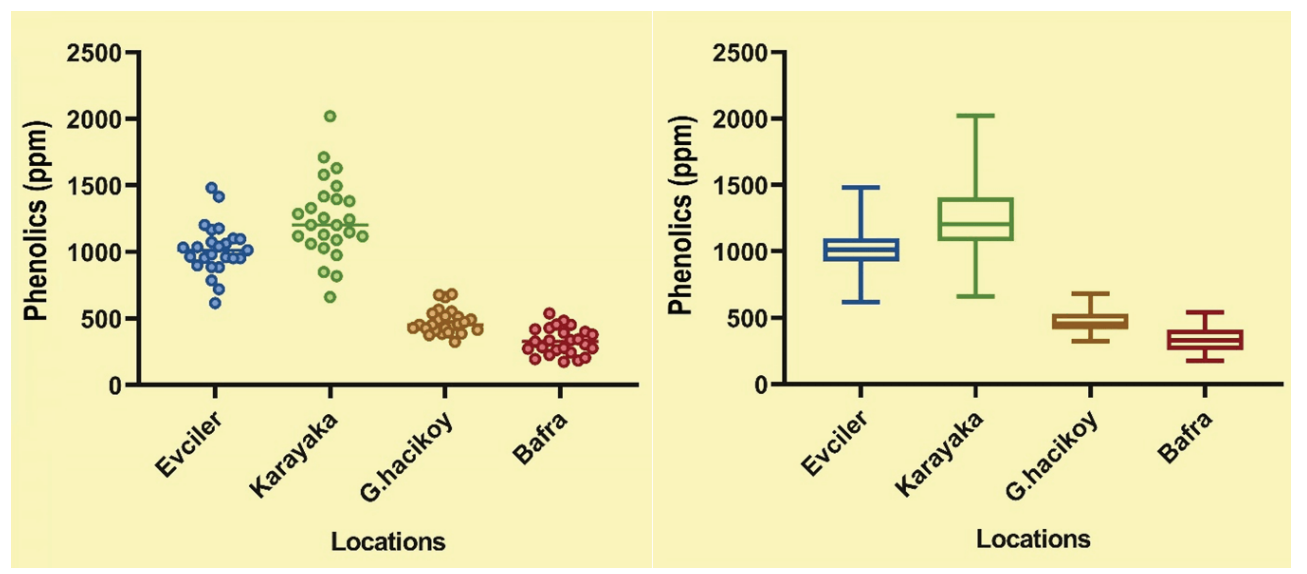

Figure 5. Variation in phenolics (chlorogenic acid + rutin) content of 25 tobacco genotypes at four different locations. 
rapidly, depending on the severity of the enzymatic activity on the first and second day during curing and subsequently decreases related to the browning reaction (44). The duration and regime of climatic events have a significant impact on the chemical structures of tobacco lines grown in the experimental locations. The prolongation of curing processes in Gümüşhacıköy and Bafra locations had a negative effect on the accumulation of phenolic compounds.

\section{CONCLUSION}

The tobacco plant has a high adaptability and demonstrates unique characteristics in the common growing regions. Central Black Sea region tobacco type is a type of oriental tobacco in high demand despite the higher cost of raw material compared to other tobacco types. In this study, 21 Basma type tobacco lines, which stand out in regard to some characteristics, have been tested in four locations where the tobacco production is common. With a number of checks, their performances were monitored and the effects of ecological differences on tobacco quality were determined. Chemical composition of tobacco leaves was significantly different among locations where ecological conditions, such as light, humidity, precipitation, altitude and temperature were different from each other. Information on chemical composition of tobacco leaves is important to develop new blends or to sustain the quality of existing blends. Despite additives such as casing ingredients, flavors, or humectants in blends, the main source of taste perceived by smokers is the tobacco. Detailed studies in Oriental tobaccos with a focus on the secondary metabolites, especially phenolics, which are affected by the environmental conditions will be useful.

\section{ACKNOWLEDGEMENTS}

This study was funded by the Republic of Turkey's Tobacco and Alcohol Market Regulatory Authority (Project name: Determination of Lines with Superior Characteristics in Tokat Region Basma Type Tobaccos) and this paper summarizes the results from the $\mathrm{PhD}$ thesis of the author.

\section{REFERENCES}

1. Dimitrova, S.: Study on Growth Characteristics of Oriental Tobacco Varieties Under Northern Bulgaria II. Ticha 117 Variety; Presented at the Proceedings of the Jubilee International Scientific Conference "Bulgaria of Regions", May 19-21, 2005 in Plovdiv, Bulgaria.

2. Radoukova, T.I. and Y.K. Dyulgerski: Comparative Study on the Effect of the Climatic Conditions on Biological, Economic and Chemical Characteristics of Large-Leaved Tobacco Samples of Burley and Virginia Groups; Ecologia Balkanica 5 (2014) 49-54. Available at: http://web.uni-plovdiv.bg/mollov/EB/2014_vol5_ SE/049-054_eb.SE13211.pdf (accessed July 2020)

3. Paunescu, M., A.D. Paunescu, A. Ciuperca, V. Udrescu, and E. Udrescu: Studies Concerning the Release of
New Oriental Tobacco Genotypes with Superior Characteristics of Taste and Aroma; Poster presented at the CORESTA Meeting Agronomy/Phytopathology, October 13-15, 2003 in Bucharest, Romania. Available at: https://www.coresta.org/abstracts/studies-concerning -release-new-oriental-tobacco-genotypes-superiorcharacteristics-taste (accessed July 2020)

4. Bilgin, A.E., Y. Muftuoglu, and A. Usturali: Calibration of Oriental Tobaccos by Commercial Fertilizer Requirements and Phosphorus-Potassium Analysis Methods in the Aegean Region; Aegean Agricultural Research Institute Publications No.195, Izmir, Turkey, 1993.

5. Usturali, A., R. Apti, R. Otan, G. Yazan, and H. Sengul: Selection Studies on Sarıbağlar Subpopulation in the Aegean Tobacco Region; Anadolu - J. Aegean Agric. Res. Inst. 8 (1998) 1-15.

6. Ahmed, S., F. Mohammad, Q. Ahmed and M.A.U. Khan: Assessing Genetic Variation for MorphoAgronomic Traits of Some Native and Exotic FCV Tobacco Genotypes in Pakistan; Am. Eurasian J. Agric. Environ. Sci. 14 (2014) 428-433.

DOI: 10.5829/idosi.aejaes.2014.14.05.12329

7. Brück, H., C. Jureit, M. Hermann, A. Schulz, and B. Sattelmacher: Effect of Water and Nitrogen Supply on Water Use Efficiency and Carbon Isotope Discrimination in Edible Canna (Canna edulis Ker-Gawler); Plant Biol. 3 (2008) 326-334. DOI: $10.1055 / \mathrm{s}-2001-16450$

8. Senbayram, M., S. Ekren and S. Sekin: Effects of Ecological Conditions and Nutrients on Oriental Tobacco Quality; Presented at the Workshop on Tobacco Farming and Problems in the Aegean Region, Izmir, Turkey December 21, 2005.

9. Xia, B., M. Feng, G. Xu, J. Xu, S. Li, X. Chen, L. Ding and Y. Zhou: Investigation of the Chemical Compositions in Tobacco of Different Origins and Maturities at Harvest by GC-MS and HPLC-PDA-QTOF-MS; J. Agric. Food Chem. 62 (2014) 4979-4987. DOI: $10.1021 /$ jf5009204

10. Clark, M.S.G., M.J. Rand, and S. Vanov: Comparison of Pharmacological Activity of Nicotine and Related Alkaloids Occurring in Cigarette Smoke; Arch. Int. Pharmacodyn. Ther. 156 (1965) 363-379.

11. Talhout, R., A. Opperhuizen, and J.G.C. van Amsterdam: Sugars as Tobacco Ingredient: Effects on Mainstream Smoke Composition; Food Chem. Toxicol. 44 (2006) 1789-1798. DOI: 10.1016/j.fct.2006.06.016

12. Roemer, E., M.K. Schorp, J.J. Piadé, J.I. Seeman, D.E. Leyden, and H.J. Haussmann: Scientific Assessment of the Use of Sugars as Cigarette Tobacco Ingredients: A Review of Published and Other Publicly Available Studies; Crit. Rev. Toxicol. 42 (2013) 244-278. DOI: $10.3109 / 10408444.2011 .650789$

13. Hasebe, H. and S. Subara: The Quality Estimation of Different Tobacco Types Examined by Headspace Vapor Analysis; Beitr. Tabakforsch. Int. 18 (1999) 213-222. DOI: $10.2478 /$ cttr-2013-0685

14. Leffingwell, J.C.: Chemical Constituents of Tobacco Leaf and Differences Among Tobacco Types; Leffingwell Reports 1, pp 1-56, 2001. Available at: http://www.leffingwell.com/download/tobacco_ 
chemistry.pdf (accessed August, 2020).

15. Xie, F., A. Yu, D. Hou, H. Liu, L. Ding and S. Zhang: Rapid and Sensitive Analysis of Eight Polyphenols in Tobacco by Rapid Resolution Liquid Chromatography; Am. J. Anal. Chem. 2 (2011) 929-933. DOI: 10.4236/ajac.2011.28107

16. Bazinet, L., Y. De Grandpré, and A. Porter: Electromigration of Tobacco Polyphenols; Sep. Purif. Technol. 41 (2005) 101-107. DOI: $10.1016 /$ j.seppur.2004.05.003

17. Wang, H.Y., M.M. Zhao, B. Yang, Y.M. Jiang, and G.H. Rao: Identification of Polyphenols in Tobacco Leaf and Their Antioxidant and Antimicrobial Activities; Food Chem. 107 (2008) 1399-1406. DOI: 10.1016/j.foodchem.2007.09.068

18. Xiang, G., H. Yang, L. Yang, X. Zhang, Q. Cao, and M. Miao: Multivariate Statistical Analysis of Tobacco of Different Origin, Grade and Variety According to Polyphenols and Organic acids; Microchem. J. 95 (2010) 198-206. DOI: 10.1016/j.microc.2009.12.001

19. Sun, Y., W. Li, J. Wang, J. Bi and S. Su: Determination of Rutin in Cigarette Tobacco, Filters, Mainstream Smoke and Burned Ash of Different Branded Cigarettes by High Performance Liquid Chromatography; Molecules 17 (2012) 3751-3760.

DOI: $10.3390 /$ molecules 17043751

20. Ji, X., Y. Wei, G. Liu, and H. Chen: Quantitative Determination of Polyphenols in Tobacco Leaves by HPLC; J. Food, Agric. Environ. 11 (2013) 868-870.

21. McCue, J.M., K.L. Link, S.S. Eaton, and B.M. Freed: Exposure to Cigarette Tar Inhibits Ribonucleotide Reductase and Blocks Lymphocyte Proliferation; J. Immunol. 165 (2000) 6771-6775.

DOI: $10.4049 /$ jimmunol.165.12.6771

22. Vaughan, C., S.B. Stanfill, G.M. Polzin, D.L. Ashley, and C.H. Watson: Automated Determination of Seven Phenolic Compounds in Mainstream Tobacco Smoke; Nicotine Tob Res. 10 (2008) 1261-1268.

DOI: $10.1080 / 14622200802123146$

23. Pang, T., C. Bai, Y. Xu, G. Xu, Z. Yuan, Y. Su, and L. Peng: Determination of Sugars in Tobacco Leaf by HPLC with Evaporative Light Scattering Detection; J. Liq. Chromat. Relat. Technol. 29 (2006) 1281-1289. DOI: 10.1080/10826070600598993

24. Cai, K., D. Hua, B. Lei, H. Zhao, W. Pan, and B. Song: Determination of Carbohydrates in Tobacco by Pressurized Liquid Extraction Combined with a Novel Ultrasound-Assisted Dispersive Liquid-Liquid Microextraction Method; Anal. Chim. Acta 882 (2015) 90-100. DOI: 10.1016/j.aca.2015.03.013

25. Kurt, D.: Genotype $\times$ Environment Interactions of Basma Type Tobacco (Nicotiana tabacum L.) Lines Selected for Superior Characteristics; PhD Thesis, Gaziosmanpasa University Graduate School of Sciences, Tokat Turkey, 2019.

26. Kinay, A: Effects of Different Nitrogen Rates on Yield and Quality of Tobacco (Nicotiana tabacum L.); MSc Thesis, Gaziosmanpasa University Graduate School of Sciences, Tokat, Turkey, 2010.

27. Kurt, D.: Effect of the Different Fertilizer Sources and Doses on Yield and Quality in Organic Tobacco (Nicotiana tabacum L.) Production; MSc Thesis,
Ondokuz Mayis University Graduate School of Sciences, Samsun, Turkey, 2011.

28. Moghbel, N., B. Ryu, and K.J. Steadman: A ReversedPhase HPLC-UV Method Developed and Validated for Simultaneous Quantification of Six Alkaloids from Nicotiana spp.; J. Chrom. B 997 (2015) 142-145. DOI: $10.1016 /$ j.jchromb.2015.06.006

29. Kinay, A: Effects of Cadmium on Nicotine, Reducing Sugar and Phenolic Contents of Basma Tobacco Variety; Fresen. Environ. Bull. 27 (2018) 9195-9202.

30. Nagai, A., T. Yamamoto, and H. Wariishi: Identification of Fructo- and Malto-Oligosaccharides in Cured Tobacco Leaves (Nicotiana tabacum L.); J. Agric. Food Chem. 60 (2012) 6606-6612. DOI: $10.1021 / j f 301395 v$.

31. Dagnon, S., A. Edreva, and A. Vladovska: Colour and Aroma of Tobacco: A Facilitated Approach for Their Objective Evaluation in Oriental Tobaccos and for Cultivar Classification Within Virginia and Oriental Tobacco Types; Presented at the CORESTA Congress, Agronomy-Phytopathology Groups, Paris, France, October 15-20, 2006.

32. Aytac, B.: Determination of Nail Tobacco Line Performance in Different Locations in Bafra; MSc Thesis, Ondokuz Mayis University Graduate School of Sciences, Samsun Turkey, 2016.

33. Sekin, S.: Tobacco Quality and Difficulties in Measuring it; Presented at the Turkey Tobaccos and Future Symposium, Tokat, Turkey, November 12-14, 1986.

34. Tuncay, H., S. Sekin, and A. Ozcam: Soil Properties of Tobacco Growing Soils in Akhisar-Manisa Region and Relationships Between Soil Properties and Tobacco Quality; Doga - Turk. J. Agric. Forest. 10 (1985) 3-12.

35. Müftüoğlu, Y.: The Relationship Between the Chemical Structure and Quality Characteristics of Tobacco and Soil Elements; Aegean Agricultural Research Institute Publications No. 57, Izmir, Turkey, 1985.

36. Goksun, V.: Determination of Heavy Metal Uptake of Tobacco at Different Irrigation and Cadmium Levels; MSc Thesis, Mustafa Kemal University Graduate School of Sciences, Hatay, Turkey, 2009.

37. Yazan, G.: Correlation Between Color Characteristics and Quality Grading Values of Some Resistant Tobacco Varieties and Lines on Blue Mold; Anadolu J. Aegean Agric. Res. Inst. 2 (1992) 51-72.

38. Eser, M.: A Comparative Study in Respect of Anatomy, Morphology and Mineral Material Content on the Bafra Örencik Type of Nicotiana tabacum L. (Solanaceae) Growing on Plateau and Slope Areas; MSc Thesis, Ondokuz Mayis University Graduate School of Sciences, Samsun, Turkey, 1994.

39. Bilalis, D.J., I.S. Travlos, J. Portugal, S. Tsioros, Y. Papastylianou, Y. Papatheohari, C. Avgoulas, I. Tabaxi, E. Alexopoulou, and P.J. Kanatas: Narrow Row Spacing Yield and Decreased Nicotine Content in Sun-Cured Tobacco (Nicotiana tabacum L.); Ind. Crops Prod. 75 (2015) 212-217.

DOI: $10.1016 /$ j.indcrop.2015.05.057.

40. Camas, N., H. Karaali, O. Caliskan and D. Kurt: Determination of the Yield and Yield Components of Basma Tobacco Cultivars and Accessions under Gumushacikoy Conditions; Presented at the VIII. 
Turkey Field Crops Congress, Hatay, Turkey, October 15-20, 2009.

41. Odabasoglu, M.: Tobacco Chemistry; Ondokuz May1s University Science Faculty Publications No. 90, Samsun, Turkey, 1994.

42. Aksu, S. and G.M. Elmas: Tobacco Chemistry and Technology; Istanbul University Forestry Faculty Publications No. 4, Istanbul, Turkey, 1993.

43. Darvishzadeh, R., L. Mirzaei, H.H. Maleki, H. Laurentin, and S.R. Alavi: Genetic Variation in Oriental Tobacco (Nicotiana tabacum L.) by Agro-Morphological Traits and Simple Sequence Repeat Markers; Rev. Cienc. Agron. 44 (2013) 347-355. DOI: $10.1590 /$ S1806-66902013000200018

44. Yazan, G. and A.S. Gencer: Determination of Polyphenol Compounds in Aegean Region Tobacco and Investigation of Their Effects on Smoke Condensate; Presented at the IV. Turkey Field Crops Congress, Tekirdag, Turkey, September 17-21, 2001.

45. Camas, N.: The Analysis of the Inheritance Ability of Some Quantitative Characters Using Line $\times$ Tester Method in Tobacco (Nicotiana tabacum L.); Ph.D. Thesis, Ondokuz Mayis University Graduate School of Sciences, Samsun Turkey, 1998.

46. Camas, N., E. Esendal, S. Aytac, and A.K. Ayan: Determination of the Inheritance of Some Traits According to Single Sequence Analysis Method in Breeding of Hybrid Variety in Tobacco: I. Yield and Some Morphological Properties; Presented at the II. Turkey Field Crops Congress, Samsun, Turkey, September 22-25, 1997.

47. Esendal, E., A.K. Ayan, S. Aytac and N. Camas: Analysis of Some Characteristics of Tobacco Lines Collected From Bafra Populations; Presented at the II. Turkey Field Crops Congress, Samsun, Turkey, September 22-25, 1997.

48. Esendal, E., A.K. Ayan, S. Aytac and N. Camas: Analysis of Some Characteristics of Tobacco Lines Collected From Bafra Populations; Presented at the IV. Turkey Field Crops Congress, Tekirdag, Turkey, September 17-21, 2001.

49. Esendal, E., A.K. Ayan, S. Aytac, N. Camas, and O. Caliskan: Analysis of Properties of Some Tobacco Lines From Bafra; Presented at the VII. Turkey Field Crops Congress, Erzurum, Turkey, June 25-27, 2007.

50. Baker, R.R., J.R. Pereira da Silva, and G. Smith: The Effect of Tobacco Ingredients on Smoke Chemistry. Part I. Flavourings and Additives; Food Chem. Toxicol. 42 (2004) 3-37. DOI: 10.1016/S0278-6915(03)00189-3

51. Baker, R.R., J.R. Pereira da Silva, and G. Smith: The Effect of Tobacco Ingredients on Smoke Chemistry. Part II. Casing Ingredients; Food Chem.Toxicol. 42 (2004) 39-52. DOI: 10.1016/j.fct.2003.08.009
52. Clarke, M.B., D.Z. Bezabeh, and C.T. Howard: Determination of Carbohydrates in Tobacco Products by Liquid Chromatography-Mass Spectrometry/Mass Spectrometry: A Comparison With Ion Chromatography and Application to Product Discrimination; J. Agric. Food Chem. 54 (2006) 1975-1981.

DOI: $10.1021 / \mathrm{jf052925+}$

53. Rodgman, A. and T.A. Perfetti: The Chemical Components of Tobacco and Tobacco Smoke; CRC Press, Taylor \& Francis Group, Boca Raton, FL, USA, 2009, pp. 1815.

54. Dagnon, S., P. Zaprianova, and A. Edreva: Colour and Aroma in Virginia Tobaccos as Influenced by the Polyphenol and Essential Oil Cultivar Characteristics: A Chemometric Approach; Biotechnol. Biotechnol. Equip. 20 (2006) 23-29. DOI: $10.1080 / 13102818.2006 .10817299$

55. Chang, J., J. Luo, and G. He: Regulation of Polyphenols Accumulation by Combined Overexpression/ Silencing Key Enzymes of Phyenylpropanoid Pathway; Acta Biochim. Biophys. Sin. (2009) 123-130. DOI: $10.1093 /$ abbs/gmn014.

56. McGrath, T.E., A.P. Brown, N.K. Meruva, and W.G. Chan: Phenolic Compound Formation from the Low Temperature Pyrolysis of Tobacco; J. Anal. Appl. Pyrol. 84 (2009) 170-178.

DOI: 10.1016/j.jaap.2009.01.008.

57. Docheva, M., S. Dagnon, S. Statkova, and D. Dimanov: Isolation of Bioflavonoids From Tobacco; Trakia J. Sci. 10 (2012) 79-83.

58. Dagnon, S. and A. Edreva: Application of Pattern Recognition Method for Color Assessment of Oriental Tobacco Based on HPLC of Polyphenols; Beitr. Tabakforsch. Int. 20 (2003) 355-359. DOI: $10.2478 /$ cttr-2013-0750.

59. Oten, M., S. Albayrak, S. Kiremitci and M. Turk: Determination of Yield and Quality Parameters of Some Alfalfa (Medicago sativa L.) Genotypes in the Mediterranean Region of Turkey; Fresenius Environ. Bull. 27 (2018) 7627-7633.

Address for correspondence:

Dursun Kurt, Ph.D.

Ondokuz Mayis University

Vocational High School of Bafra

Samsun, Turkey

E-mail:dursun.kurt@omu.edu.tr 